\title{
Ernest P. Young, Ecclesiastical Colony: China's Catholic Church and the French Religious Protectorate,
} Oxford, Oxford University Press, 2013, 383 pp.

Pierre Vendassi

Translator. N. Jayaram

\section{OpenEdition}

1 Journals

Electronic version

URL: http://journals.openedition.org/chinaperspectives/6751

DOI: $10.4000 /$ chinaperspectives.6751

ISSN: 1996-4617

Publisher

Centre d'étude français sur la Chine contemporaine

\section{Printed version}

Date of publication: 1 June 2015

Number of pages: $70-71$

ISSN: 2070-3449

\section{Electronic reference}

Pierre Vendassi, «Ernest P. Young, Ecclesiastical Colony: China's Catholic Church and the French Religious Protectorate, », China Perspectives [Online], 2015/2 | 2015, Online since 01 January 2017, connection on 22 September 2020. URL : http://journals.openedition.org/chinaperspectives/6751 ; DOI : https:// doi.org/10.4000/chinaperspectives.6751 


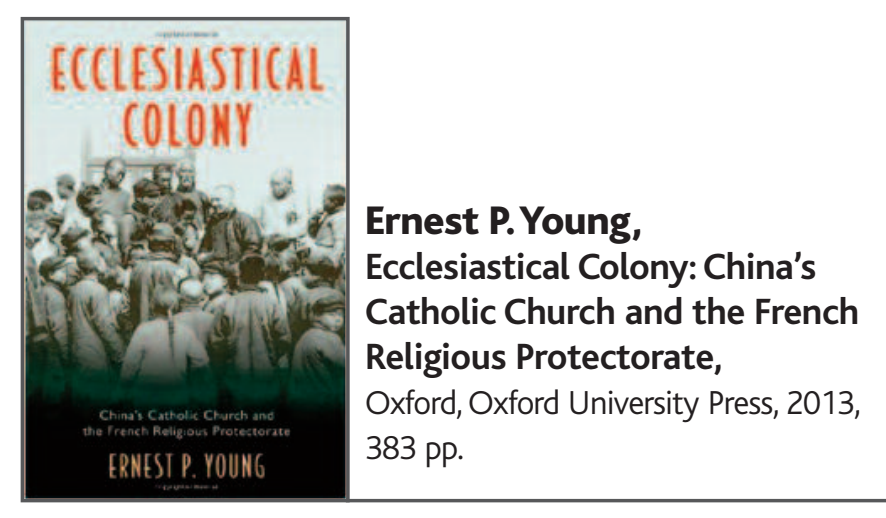

PIERRE VENDASSI

E rnest P. Young's book considers "the conjuncture of the catholic immersion in imperialism as it developed in the nineteenth century in China and the struggle within the church against that linkage in the first decades of the twentieth century" (p. 1). It seeks to explain how, following a growth period in the first half of the nineteenth century, the Catholic Church faced growing hostility in the subsequent decades, the most emblematic manifestation of it being the Boxer Rebellion in 1900. Rejecting cultural explanations of a clash of civilisations, the author admits, as other scholars have done, that "the dependency of the Christian missions on the unequal treaties" (p. 8), leading to an assimilation of the religious project into an imperialist political one, was an essential part of the problem. He also offers an institutional dimension to the explanation: the installation, in the framework of unequal treaties, of a French religious protectorate, through which France acted as the guardian of China's Catholics, helped the latter benefit from a regime of extraterritoriality, irrespective of nationality.

In a 259-page exposition (followed by 82 pages of notes, a four-page glossary of Chinese terms, a 30-page bibliography and about ten pages of index), the book explores the history of the French protectorate, examining how such an institutional arrangement took shape and lasted for several decades despite the opposition its conception and application inevitably generated.

The book's initial chapters (1 to 3 ) shed light on the contextual and strategic causes explaining the formation of the protectorate, beginning with a convergence of interests between Chinese authorities trying to divide colonial powers by granting them unequal privileges, French authorities wishing to use Catholicism for political and economic ends, and Catholic missionaries seeing in the protectorate a means of striking deeper roots in China.

While detailing the conditions under which this institutional arrangement emerged, the author also describes the immediate perverse effects it had, such as the assimilation of the Catholic religious project into the imperialist one and the conceding of immunity - impunity, even - to foreign missionaries that many accounts depict as generally ambitious, iniquitous, little concerned with evangelisation and distrusting - often to an extreme - the local populations, thus largely obstructing the process of indigenisation of the Church.

Young devotes much space (Chapters 2, 4, and 5) to a crucial aspect of the protectorate, namely the settling of jiao'an, or often violent incidents pitting Catholics against non-Catholics, leading quasi-systematically to demands for reparation on the part of French missionaries and authorities. These jiao'an most often concluded with financial compensations and severe condemnation of those opposed to the Church, which needless to say met with strong feelings of injustice among the gentry and local populations, resulting in further hostility towards Catholics in a backdrop of growing nationalism.

The largest and best known instance of opposition, the Boxer Rebellion, is revelatory as regards the vicious circle the protectorate initiated: French authorities ask for higher indemnities to compensate the losses of missionaries and Catholic laity killed during the rebellion; the Chinese government, in order to forestall the latent threat of a military retaliation, submits to foreign pressures, which only entrenches foreign presence in China; the indemnities obtained are handed over to the missions, although they are not used for the benefit of local communities; foreign missionaries continue with their allegiance to the protectorate, while the local populations have to fund the foreign missionaries through these indemnities. Hostility could only rise, whereas the reputation of the Church and its agents shrank.

The book's second part (Chapters 6 to 10) dwells on the rising calls for dismantling the protectorate and for the Church's indigenisation launched by Chinese Catholics and some rare emblematic missionaries, especially after 1916, and attempts to expand the French concession in Tianjin. The author notes the opposition to these reformists from the protectorate's partisans, prominent among them a majority of foreign missionaries, whose prejudices as well as ambitions seemed to have made them resistant to the very idea of ordaining Chinese bishops. He also notes the Vatican's conversion to the idea of a need for change. Previously dissuaded by France from retaking control of the Church in China, the Catholic authorities in Rome ended up seeing the indigenisation strategy as necessary for ending the impasse into which the protectorate had plunged the Church. Braving French opposition as well as its own missionaries' inertia, the Catholic authorities encouraged a movement towards indigenisation starting from the 1920s, which led to the protectorate's weakening to a large extent.

In the final chapter, the author shows that it was in fact the mutations in the French colonial strategy adopted during the Second World War, combined with the Japanese invasion and the arrival of Mao's regime, that finally dented the protectorate.

One of the book's strengths clearly lies in the author's ability to shed light on this history with the help of carefully set out facts and rigorous analyses. Through related events and a small number of archetypical personages who hold up the narrative (they are described in an introduction akin to a film synopsis), the logic of social change becomes clear: ideological conflicts, collective or individual strategies still limited rationally, resistance to change, the power of minorities, and the weight of contingencies. A question arises as to whether the author's talent for introducing grand history in a coherent narrative thread, a drama depicting a relatively restricted number of iconic personages, might not at times have risked inducting hero worship into the account.

The book's contribution resides in its inclusion of significant elucidations of empirical events, which when interpreted in light of nationalist or Maoist ideological postures helped to legitimise the installation of an anti-imperialist religious policy in China, the effects of which are felt even now - and especially by Catholics.

Moreover, while it deals with a very specific period and place, the book would be useful in sparking reflection and debates of great currency, furnishing as it does a perfect illustration of the way in which the religious domain is ceaselessly used for political ends, without ever being reduced to only this instrumentalisation. Young thus brings out the plural, ambiguous, and unpredictable character of religious enterprises, which flaunt apparent 
unity but are nevertheless the work of actors whose values and aims remain extremely varied. From this viewpoint, the perspective given of the Catholic Church in the early twentieth century has an altogether Gramscian touch.

Finally, although the author has sought to deflect this criticism right at the book's outset, it is a pity that there is little discussion of "indigenous" Catholics, who seem to take a secondary place in the book despite the presence of some salient figures. Of course, the author's stance in favour of an institutional approach, the fact that the institution in question mostly distrusted the local populations in the period covered, and the repercussions this could have eventually in terms of presence and representation in avail- able sources no doubt suffice to justify this lacuna. This in any case in no way diminishes the value of this book, which may be recommended to anyone interested in China's political and religious history, as well as to specialists in contemporary religion, or even to anyone seeking to benefit, through empirical facts, from a relative reflection on the logic of globalisation.

\section{Translated by N. Jayaram.}

I Pierre Vendassi holds a PhD in sociology and is associate researcher at the Centre Emile Durkheim, University of Bordeaux (pierrevendassi@yahoo.fr).

\section{Books received}

Roland Altenburger, Margaret B. Wan, and Vibeke Børdahl (eds), Yangzhou, A Place in Literature: The Local in Chinese Cultural History, Honolulu, University of Hawaili Press, 2015, 510 pp.

Ruoyun Bai, Staging Corruption: Chinese Television and Politics, Hong Kong, HKU Press, 2014, 276 pp.

Yongshun Cai, State and Agents in China: Disciplining Government Officials, Stanford, Stanford University Press, 2015, 252 pp.

Bill Hayton, The South China Sea:The Struggle for Power in Asia, New Haven, London, Yale University Press, 2014,298 pp.

Michel Hockx, Internet Literature in China, New York, Columbia University Press, 2015, 251 pp.

Elaine Jeffreys and Haiqing Yu, Sex in China, Cambridge, Malden, Polity Press, 2015, 232 pp.

Jacques deLisle and Avery Goldstein (eds), China's Challenges, Philadelphia, University of Pennsylvania Press, 2015, 317 pp.

Lu Xun (edited by Sebastian Veg), Nouvelles et poèmes en prose, Paris, Étitions Rue d'Ulm, 2015, 663 pp.

Judith Pernin, Pratiques indépendantes du documentaire en Chine: histoire, esthétique et discours visuels (1990-2010), Rennes, Presses universitaires de Rennes, 2015,289 pp.

Christopher Rea and Nicolai Volland, The Business of Culture: Cultural Entrepreneurs in China and Southeast Asia, 1900-65, Hong Kong, HKU Press, 2015, 329 pp.

Michael T. Rock and Michael A. Toman, China's Technological Catch-Up Strategy: Industrial Development, Energy Efficiency, and $\mathrm{CO}_{2}$ Emissions, Oxford, Oxford University Press, 2015, 274 pp.

Vera Schwarcz, Colors of Veracity: A Quest for Truth in China, and Beyond, Honolulu, Univeristy of Hawaili" Press, 2014, 171 pp.

Clément Séhier and Richard Sobel (eds), Travail, luttes sociales et régulation du capitalisme dans la Chine contemporaine, Villeneuve d'Ascq, Presses Universitaires du Septentrion, 2015, 178 pp.

Lawrence R. Sullivan and Nancy Y. Liu, Historical Dictionary of Science and Technology in Modern China, Lanham, Rowman \& Littlefield, 2015, 547 pp.

Luigi Tomba, The Government Next Door: Neighborhood Politics in Urban China, Ithaca, London, Cornell University Press, 2014, 225 pp.

Dan Wang, The Demoralization of Teachers: Crisis in Rural School in China, Lanham, Lexington Books, 2013, 149 pp.

Scott Wilson, Tigers without Teeth: The Pursuit of Justice in Contemporary China, Lanham, Rowman \& Littlefield, 2015, 260 pp.

Xiaowei Zang, Ethnicity in China, Cambridge, Malden, Polity Press, 2015, 236 pp. 